\title{
50th Anniversary of Un-Americanism in Seattle
}

\author{
“The All Powers Project," University of Washington, January-March 1998
}

In 1948, 100 years after the publishing of the Communist Manifesto, the President and the Board of Regents of the University of Washington (UW) in Seattle began a national trend by being the first school to fire tenured professors for their political affiliation with the Communist Party, or for their refusal to cooperate with "hearings." This set a precedent for the national purge to follow, including McCarthy's House Un-American Activities Committee which convened several years later. In all, 80 hearings were held on campuses throughout the country.

Beginning in January of 1998, UW presented "The All Powers Project," which includes lectures, panel discussions, and an exhibit to mark the 50th anniversary of Un-Americanism hearings on campus. The School of Drama simultaneously staged a play through the middle of February at the UW Playhouse Theater, entitled "All Powers Necessary and Convenient." All the events for the Project were well attended. In fact, the entire run of the play was sold out long in advance of its opening. There were organized discussions on the evenings of the first and last performances. Discussions occurred spontaneously after performances on the other nights as well.

Anti-Communism did not appear out of nowhere, but was fertilized by a long tradition of anti-labour and anti-socialist agitation. The Board of Regents of UW had imposed a political speaker ban as early as 1911. The Russian Revolution gave impetus to the "first red scare." The US passed the Deportation Act of 1918, which allowed for a wholesale deportation of political activists. On December 21, 1919, 249 people were deported. Not satisfied with this Draconian legislation, in 1920, Congress discussed the Graham Bill, which proposed the death penalty for "sedition."

The US government and the media had fomented anti-Communist hysteria from the time of the Russian Revolution in 1917 until 1942. In 1942 and 1943, there was a brief respite, as the US Government turned its efforts towards convincing Americans that they wanted to be allies with the USSR. This proSoviet propaganda abruptly ended with President Truman's institution of loyalty checks. In 1946, 308 federal employees were fired as security risks, and anti-Communist frenzy was back with a vengeance.

The state legislature and the administration of UW used anti-democratic tactics to suppress radical and progressive tendencies within the University and the greater community. Three tenured professors were fired, and many more were confronted and questioned by members of the Canwell Committee on UnAmerican Activities. Fourteen people were subpoenaed to appear before the Canwell Committee, including nine UW professors, four non-professors, and a city employee. Prior to the hearings, Ralph Gundlach wrote prophetically to 


\section{Left History 5.2}

several colleagues: "The strategy of the Canwell Committee is really to split up those who have been subpoenaed so that a number of persons may be fired, to the great relief of those challenged but missed who can then thankfully fight a losing battle for those discharged."

Gundlach was one of three tenured professors who were fired and who were never able to work in academia again. These three refused to answer any questions from the committee, because they felt speaking to them added legitimacy to the witch-hunt. Dr. Herbert Phillips, another of the three fired, was said to be one of the finest teachers that ever sat on the faculty of the UW. Joseph Butterworth was the third professor who was fired. These were all exceptional teachers. Butterworth suffered personal tragedy as his wife committed suicide before the hearings. Gundlach was fined $\$ 250$ and imprisoned for 30 days. Garland Ethel, another professor forced to testify in the hearings, answered questions about himself and avoided being fired, however he did refuse to name associates in the Party. Harold Eby and Melville Jacobs who testified after him were heartened by his resolve, and refused to name names. Ethel, Eby, and Jacobs were nearly fired because they denied past membership in the $\mathrm{CP}$ on the advice of their lawyers. They finally remained, but on probation for two years after being forced to sign an affidavit promising not to engage in outside political activities. According to UW President Allen, the fired professors were "incompetent to teach" and "derelict in duty."

Members of the Canwell Committee included two Democrats and five Republicans. One Democrat, Rep. George F. Yantis, had been appointed by the speaker of the house to moderate Canwell's "witch-hunting fervor" (according to Jane Sanders in Cold War on the Campus). Yantis died in December 1947, before the hearings began. The hearings took place on the second floor of the armory, now the Center House of Seattle Center. Canwell had a list of forty faculty members he suspected of being communists. According to Ellen Schrecker (author of No Ivory Tower), J. Edgar Hoover's FBI gave memoranda with people's affiliations to the governors of states. These memoranda were blind, on paper without letterhead. These covert communications of unproven allegations negatively affected 800 people nationally.

Canwell also accused Ted Astley who was in the administration as a Student Veterans Counselor, not on the faculty, and Rachmael Forschmieldt who worked for the City of Seattle Health Department. He also accused Burton and Florence Bean James and Albert Ottenheimer, who had founded their own theater company, the Seattle Repertory Playhouse. This allowed a negotiator for the University to intimidate the owner of the building holding the theater to turn it over to the University on overly generous terms. The negotiator stated that if they did not, the building would be condemned, and thus the James's lost the building.

The US House Un-American Activities Committee focused activities on college campuses in the early 1950's. Like the Salem witch-trials and Stalin's 
inquisitions, the HUAC required recantations, and demanded that people name names. Companies such as Boeing in Seattle, and GE, fired workers who exercised their constitutional right by taking the fifth amendment.

John Caughlan, considered the lawyer for communists in Seattle during that time, with partner Barry Hatten and Sarah Lesser, was the civil liberties lawyer for some of the defendants, and is today still an activist in Seattle. Defending Communists caused considerable negative personal effects on Caughlan and on his family. There were economic costs in not getting legal cases, financial hardships causing tension, and also personal attacks. At one point Caughlan was tried for perjury, for which he was later acquitted. There were even obscene phone calls received by his children. Despite all this, he has a very positive outlook, and remains hopeful for the future.

Caughlan has had an impressive history as a citizen and civil libertarian. $\mathrm{He}$ spent a year studying classics in a $\mathrm{PhD}$ program at Yale, but then changed direction and entered Harvard Law School in 1932. He was interested in working in labor law upon graduation, but worked for a year for a corporation. He then entered a conservative law office, and also became secretary for ACLU in Washington State. Terms of his employment included that he could have private cases, but the law office threw him out because he accepted privately a civil liberties case representing the CP. The ACLU also kicked him out, without due process. At that time the ACLU was afraid of being "tainted" by communism. Thus was the beginning of Caughlan's career as a civil liberties lawyer. Ironically, twelve years ago the ACLU awarded him the most prestigious award of the Washington chapter, the William O. Douglas award for consistent longterm efforts on behalf of civil liberties.

Anti-Communism was damaging, but there were a few glimmers of hope. In 1948,103 UW professors signed an open letter criticizing the firings. Albert Canwell failed to win re-election to the House in 1948 with an anti-Communist campaign.

Caughlan, who opposed Canwell, is clearly pleased that the events beginning in 1948 on the UW campus are now receiving publicity. But he was somewhat concerned that the focus of presentations in "The All Powers Project" was diverted away from what actually happened in 1948. He was especially concerned that the dismissal of professors was not explored in any great depth. If the current project has a fault, it was too academic and ignored the contemporary political issues. Questions from the audience and discussion was strictly limited, and ideas for future actions were rarely raised. Caughlan believes that the University needs to follow up with concrete and tangible steps to redress the damage done. For instance, the community theater was destroyed with the complicity of the University, and people's lives were destroyed. Discussion at the recent UW events focused more on the fact that many people were falsely accused of being Communists, rather than on whether people should be persecuted for their political affiliation. The actual issue before the Tenure Panel was 


\section{Left History 5.2}

whether it was possible for a member of the $\mathrm{CP}$ to be a good teacher, or whether mere membership in a legal party so tainted a person and their academic credentials that they could not serve, because they were presumed to be acting as a propaganda agent for a hostile foreign power. The Tenure Panel voted by substantial majority that membership in the $\mathrm{CP}$ wasn't a good reason for discharging anyone from the faculty. The president and the Board of Regents saw to it that this recommendation was over-ruled. Gundlach, not a member of the CP, but an "uncooperative" witness, was also thrown off the faculty because he would not cooperate with the president by telling if he was or was not a member of the CP.

The first step the UW made towards rectifying the tremendous mistake it made in 1948 was in 1994, when then-UW President William Gerberding officially apologized on behalf of the University, stating that what occurred was wrong.

After losing in the 1948 election, Canwell destroyed extensive files, reports, documents and records of surveillance without any authorization from the State Legislature. He started the American Intelligence Service, where he kept files on hundreds of people alleged to have links with Communism, and published a newsletter called "The Vigilante." Canwell is still living in Spokane, Washington. According to the December 1997 edition of a UW publication entitled "Columns," he expresses no regrets for the damage he did to American democracy.

Caughlan would like to see the University more tangibly admit that what it did was wrong and that it actively work to prevent this from recurring. He mentioned several ideas he had, such as renaming buildings on campus for the discharged professors, and renaming the playhouse the James Playhouse. It is currently "The Playhouse." Until three years ago it was named the Glenn Hughes Playhouse, after the man who seized the opportunity of the James's appearing before the Canwell Committee to take control of the building.

For more information, and to view photographs of the Canwell Committee and those accused, visit the UW exhibit site:

www.lib.washington.edu/exhibits/AllPowers/

John F. Ruhland

Seattle 